\title{
Caries prevalence and dmf-t index of Papuan's students with betel chewing habit
}

\author{
Yohanes Tebai, Endang Sukartini, Ayu Trisna Hayati \\ Department of Conservative Faculty of Dentistry Universitas Padjadjaran
}

\section{ABSTRACT}

The purpose of the research is to find the extent of caries prevalence and DMF-T index in Papuan's students with betel chewing habit in Cilaki Dormitory Bandung, 2007. Betel chewing habit is a chewing action of areca nut (Areca catechu Linn), betel leaves (Piper betel Folia), betel fruit (Piper betle Linn) lime talk (Calcium Hydroxide), and after chew to spended out of the mouth. The research is a descriptive research using the survey technique. Research samples are determined by purposive sampling, and a number of 80 samples are collected, consisting of Papuan's student with betel chewing habit in Bandung between 18-to-30 years of age. Research results indicated that caries prevalence is $98.75 \%$ with a DMF$T$ index of 5.46. The conclusion of the reseach is that the caries prevalence and the DMF-T in Papuan's student with betel chewing habit in Cilaki Papuan's Student Dormitory Bandung, 2007, is in the high category.

Key words: caries prevalence, DMF-T index and betel chewing

\section{INTRODUCTION}

Betel chewing is the most popular habit. ${ }^{1,2}$ This habit has been done since 200 years ago in China and India and about 200 to 600 million people do so. ${ }^{3}$ Indonesia has ethnic and habit and also tradition diversity. Betel chewing habit was been done by those ethnic groups from generation to generation and had a strong relationship with the culture. ${ }^{4}$

Betel chewing habit has been one of Papuan tradition and was almost conducted by every walks of life, either male or female, adult and children. This habit has been done since many years ago and has been run in the blood from generation to generation. We could see that by numbers of betel chewers we could find in Papua or in Java Island which occupied by Papuan people. The ran dry red saliva thrown in any particular place were proof of this habit. Other than that, betel and betel leaves still can be found in Papuan area. ${ }^{5}$

Betel chewing in Papuan area was known with "eating the betel". They used peeled areca nut then chewed it over and over with betel fruits, betel leaves and processed lime talks. Sometimes, Papuan people only chewed the betel fruit alone. Betel chewing for Papuan people was convinced to be a desert, mouth warmer and has been a habit which needs to be done every day.

Betel materials which Papuan people used such as areca nut (Areca catechu Linn), betel leaves (Piper betle Folia), and betel fruits (Piper betle Linn), and lime talk (Calcium Hydroxide). Materials in this betel chewing contained substance 
which can inhibit cariogenic bacteria growth. ${ }^{6,7,8}$

Areca nut (Areca catechu Linn) has tannin substance as an antibacterial substance which destructs bacteria toxin substance and bacteria cell protein. ${ }^{9,10}$ Lime talk has the ability to increase saliva $\mathrm{pH}$ which made it an alkali $\mathrm{pH}$ so that it can inhibit cariogenic bacteria growth. ${ }^{11}$ Betel leaves (Piper betle Folia) has a cavicol substance, phenol compound and volatile oil. Phenol compound in betel has antibacterial capacity which can destruct cell wall, cell cytoplast membrane, and denaturate bacterial protein included cell core towards Streptococcus mutans, Streptococcus viridans and Staphylococcus aureus. Cavichol in volatile oil has bactericidal effect 5 times stronger than regular phenol compound. ${ }^{7,12}$

Caries caused by Streptococcus mutans and lactobacilus which fermentated carbohydrate into acid and dissolve calcium in hydroxyapatite enamel, dentin and cementum which marked by dissolved of organic matrix. ${ }^{13}$

Based on Indonesia Ministry of Health Household Health Survey in 2001 results showed that caries prevalence in Indonesian people aged 10 years and above is $71,2 \%$ and DMF-T index on Indonesian people aged 10 years and above is 5,3 . This DMF-T index number showed that the average tooth damage per people throughout Indonesia is 5 teeth. While $\mathrm{F} /$ filled (patched tooth) value is very low in every age group, that is $0,07-0,15$ tooth. The increasing DMF-T was more dominated by $D /$ decayed (caried tooth) value and $\mathrm{M} /$ missing (plucked tooth). ${ }^{14}$ Caries prevalence in Papuan origin aged 6 to 50 years old is $23,2 \%$ and DMF-T index value is 0,75 , which means there was almost not even one single tooth which got caries in every Papuan people. ${ }^{15}$

Caries illustrated tooth damage which can be determined using DMF-T index and prevalence. DMF-T index was an arithmetic index from caries tooth, patched and lost which counted up to illustrate the caries severity in a community group. ${ }^{16}$

Betel material and its chemical substance content

Betel contain volatile oil compound. Table 2 Volatile Oil Chemical Compound Content. ${ }^{19}$

Lime talk is mineral group which come from burning of lime talk stone, which usually come from costal area. Lime talk could also found from burning results of chunam, sea shells, coral stone in sea water. These processed results is called calcium hydroxide, or known as lime talk. ${ }^{20,21}$

\section{Effect of betel chewing in oral cavity}

Areca nut (Areca catechu Linn) gave selfcleaning action due to high fiber content, other than that the shell-fiber can be used as tooth brush. Areca nut gave antiseptic effect towards hard and soft tissue of the mouth due to its selenium, tannin substance, and alkaloid element which contained in areca nut. ${ }^{22}$

Betel leaves has antimicrobial effect due to natural phenol compound in betel like kavikol and kavibetol. Betel also gave antiseptic and analgesic effect due to its eugenol content and bacteriostatic capacity of its volatile oil. Other than that, betel could also inhibit Candida albicans growth in oral cavity. ${ }^{6,7,23,24}$

Substances which in the mixture of quid materials which being used in betel chewing will enhance and react from one to another, when quid is being chewed, there will be a feeling of burning sensation inside the mouth and throat will feel crowded. After that it will stimulate saliva gland and irritate mouth mucous. ${ }^{25}$

According to Nelson, et. $a l^{26}$ mixture of quid materials in betel chewing will produce alkaloid compound like arecoline, arecaidine, guvacine, guvacoline and unite alcohol-derived compound that is phenol. ${ }^{26}$

Phenol compound has strong bactericide and fungicide effect. Tannin could be bonded with carbohydrate to form glycoside compound and also bond with protein at $\mathrm{pH}$ level 7-8 in the mouth. Tannin substance will bond protein while phenol compound will damage oral microorganism bacterial cell protein and gives antimicrobial effect. $^{27}$

\section{Systemic effect of betel chewing}

Chemical substance in betel material (Quid) will be absorbed through buccal mucous and gave systemic effect. ${ }^{28}$ In betel chewer beginners will cause nervous, slight seizure, weakness and sweating effects. ${ }^{25}$ Systemic effect of betel chewing could be bronchial spasm, cholinergic effect like Sludge syndrome with symptoms like hyper salivation and sweating, tears excretion, 
polyuria and diarrhea. In chronic betel chewers, this thing could stimulate nucleic acid protein component in oral mucous cell in such a way that it disturbed cell mitosis process. ${ }^{26}$ Alkaloid compound in the quid will induce oral mucous cell into oral sub mucous fibrosis. Even could develop into squamous cell carcinoma. ${ }^{25}$

Ether compound content in areca nut could stimulate central nervous system (CNS) which gave craving effect. ${ }^{29}$ Betel chewing effect will give clinical signs in various severity levels. Basic level will give nausea and vomiting symptoms but will diminish itself. In medium level, will give nausea, vomiting, dizziness and hypotension symptoms. While in advanced level will gave intoxicated effect with symptoms like comma, body vital activities decreasing like breathing depression, spasm of bronchus and decrease of blood pressure even causing death. ${ }^{26}$

\section{METHODS}

Population in this research is Papuan students in Cilaki Papuan's Students Dormitory in $29^{\text {th }}$ Cilaki Street in Bandung and outside dormitory. Sample which is used in this research is Papuan students with betel chewing habit. Research sample are determined using purposive sampling. Population criteria in this research are: (1) Have been doing betel chewing habit at least for five years with age from 18 to 28 years old; (2) Still doing betel chewing habit during examination; (3) Have at least 28 vital teeth in his jaw.

Research procedures are performed as follows: (1) Questionnaires spreading which consists of informed consent, identity data (name, sex, and age), and statement sheet about frequency and intensity of betel chewing, and also examination sheet; (2) Gave explanation about research procedures; (3) Respondents were asked to seat then to gargle using provided water to clean food waste and betel chewing waste; (4) Respondents were asked to open his mouth, in upright body position, looking straight forward; (5) Clinical examination towards caries by scratching blunt dental explorer to decayed teeth surfaces; (D). Observation for plucked, severely damaged and need to be plucked teeth for tooth-loss data due to caries/missing; (E) Sharp dental explorers were scratched to check filling in filled teeth for
Table 1 Betel chemical substance content. ${ }^{18}$

\begin{tabular}{cc}
\hline Substance name & Amount \\
\hline Arecoline & \\
Arekane / Arecaine & \\
Areca ïdine & \\
Guvacine & $4 \mathrm{mg} / \mathrm{g}$ from raw weight \\
Arecaidine & \\
Phenolics & $0.58 \mathrm{mg}$ from Gallic acid raw \\
weight \\
Tannin and catechu tannin \\
Alkaloid & $2.38 \mathrm{mg} / \mathrm{g}$ from raw weight \\
Gallic acid & \\
Gum\& lignin & \\
Fixed oils, peroxide \\
metals, magnesium
\end{tabular}

Explanation: 1. Guenther in 1949 and Hegnauer in 1969.

\begin{tabular}{cc}
\hline Substance name & Amount \\
\hline Phenol compound & $5.1-8.2$ \\
Kavikol & $2.2-1.8$ \\
Karvakol & $26.8-42.5$ \\
Eugenol & $0.0-1.2$ \\
Kavibetol & $8.2-15.8$ \\
Metil Eugenol & $3.6-6.2$ \\
Sineol & $7.0-14.6$ \\
Estragol & - \\
Alil Pirokatekol & - \\
Non phenol compound & - \\
Terpen & $6.2-11.9$ \\
Kariofilen & $6.7-9.1$ \\
Kadinen & - \\
Seskuiterpen & - \\
P-simen & - \\
Polimerized Oil & $2.7-4.6$ \\
Fenilpropana &
\end{tabular}

filled data; (F) Obtained caries data could be recorded as follows: D (decayed) is teeth which have one or more unfilled caries, but still can be filled; $M$ (missing) is plucked teeth or self-rotten due to caries or need to be plucked due to caries teeth. Plucked teeth because of accident or trauma are not counted. $\mathrm{F}$ (filled) is teeth with one or more fine filling and without secondary caries. Decayed (D) data only recorded once even in those teeth we could find several caries. If secondary caries were found, data still recorded as one (1) $D$ Missing $(M)$ data can be classified in two: (a) 
$\mathrm{Me}=$ plucked teeth and clearly proved that has been plucked due to caries. (b). $\mathrm{Mi}=$ teeth still available, but need to be plucked due to caries. Data are recorded in examination sheet.

\section{RESULT}

Research result could be seen in Table 3 and 4 .

Table 3. Caries Prevalence in Papuan Students with Betel Chewing Habit in Bandung.

\begin{tabular}{ccc}
\hline & $\begin{array}{c}\text { Number of } \\
\text { Respondent }\end{array}$ & Prevalence \\
\hline Sample with DMF & 79 & $98,75 \%$ \\
DMF free sample & 1 & $1,25 \%$ \\
Total & 80 & $100 \%$ \\
\hline
\end{tabular}

Table 4. Collections of Data D, F, Mi, Me in Papuan Students with Betel Chewing Habit Based on Age.

\begin{tabular}{cccccc}
\hline \multirow{2}{*}{$\begin{array}{c}\text { Age } \\
\text { (Years) }\end{array}$} & $\begin{array}{c}\text { Decayed } \\
(\mathrm{D})\end{array}$ & $\begin{array}{c}\text { Filled } \\
(\mathrm{F})\end{array}$ & \multicolumn{2}{c}{ Missing(M) } & DMF - T \\
\cline { 5 - 6 } & 14 & 2 & 1 & 1 & 18 \\
18 & 40 & 0 & 2 & 8 & 50 \\
20 & 17 & 0 & 1 & 2 & 20 \\
21 & 39 & 4 & 8 & 5 & 56 \\
22 & 29 & 1 & 7 & 0 & 37 \\
23 & 59 & 4 & 10 & 2 & 75 \\
24 & 57 & 0 & 1 & 10 & 68 \\
25 & 54 & 1 & 6 & 9 & 70 \\
26 & 6 & 3 & 5 & 0 & 14 \\
27 & 15 & 0 & 5 & 3 & 23 \\
28 & 5 & 0 & 1 & 0 & 6 \\
Total & 335 & 15 & 47 & 40 & 437 \\
\hline
\end{tabular}

\section{DISCUSSION}

Table 3 illustrated caries prevalence in Papuan students in Bandung with betel chewing habit is high as big as $98.75 \%$. This prevalence number showed the number of Papuan students with betel chewing habit in Bandung who had DMF in their teeth is 79 out of 80 Papuan students with betel chewing habit that went through examination.

Caries prevalence in Papuan students with betel chewing habit in Bandung is very high compared with research result conducted by Sujatminingsih ${ }^{15}$ in Papua which showed caries prevalence number as big as $23.2 \%$ in Papua origin people aged between 6 and 50 years old with or without betel chewing habit.

Dental caries caused by multifactorial combination. Other than etiologic, prevention and control factor, there were other factors which may influence caries prevalence and caries progressivity rate. Those factors consist of external factor (environmental factor) and internal factor (endogenous factor). ${ }^{30}$

External factors causing dental caries are carbohydrate diet, social economy status, bad behavior and habit in dental health maintenance. ${ }^{30}$ External factors which took role in caries lesion forming are social-economy status, education, habit and behavior and also geographical condition. ${ }^{31}$

According to Smendley and Syme (2000) external factors which influence caries forming is environment condition which effect food type. Consuming high-sucrose food will fasten plaque forming. ${ }^{31}$ Papuan food type generally consumes food rich in fiber like vegetables and fruits which gave self cleansing effect inside oral cavity. Papuan students in Bandung's food type nowadays are facing changes in line with various fast-foods which can easily be found in Bandung. Students are occupied with routine activities in such a way that they tend to but fast-food due to practical and time-effective reasons. Those foods contain easily fermentated carbohydrate.

Substrate in diet which potentially causing dental caries is carbohydrate group which easily fermentated like sucrose group. Sucrose is fermentated by Streptococcus mutans and lactobacilus from plaque layer which going to produce acid which cause teeth mineral dissolvation so that caries lesion is formed. ${ }^{30}$ Carbohydrate if consumed in high frequency and in a long period of time will make caries develop faster. ${ }^{17}$

Papuan students with betel chewing habit in Bandung were facing decrease frequency in betel chewing. Betel chewing frequency in Bandung is 5 times a day in three months so that only in five days in 3 months they could get good effect from chewing the betel towards inhibition of cariogenic bacteria. This declining in chewing frequency happened due to betel availability in Bandung. Betel materials in betel chewing were not provided in Bandung not like in Papua which we could easily find it in the market or in our own plantation. The 
frequency declining above matched with betel materials shipping from Papua. They chewed betel only when they got betel material package from Papua. Good effects from betel materials are less, not only because of the limited frequency of betel chewing but also from the behavior that ignores oral hygiene after chewing the betel.

Papuan students tend to ignore oral hygiene issues due to lack of motivation to maintain dental and oral health. This thing keeps on going in such a way that bad behavior was formed which damage dental and oral health like brushing the teeth only if they remember, ignoring tooth-ache and to pluck their own teeth. People with ignorance like that will have poor dental and oral health degree, which marked with high plaque score and caries index. ${ }^{32}$

Papua geographic condition is very far from Jakarta as the capital city causing infrastructure building, information and knowledge development in Papua province are more left behind compared with other areas in Java. Papua is very wide, divided into very remote, remote, and city area, which is hard to reach due to the geographic condition. These conditions causing delays in information and knowledge about dentistry.

Else than that, Papua social-economy status which most of the society is farmer, also influence dental and oral health level. Farming system in Papua was not sufficient like other areas outside Papua. Information delays about how to manage existing field also decreasing the productivity of local farmers. Other thing which also influenced farmers' productivity level is the marketing system which has not been available yet.

We could see from table 4 above that number of filled caries teeth is very small, only 15 teeth, while the data were dominated by number of unfilled caries teeth (D) in 335 teeth. This showed that most of Papuan students do not have the motivation to visit the dentist in order to get dental and oral health services. Each individual are best to visit dentist regularly every 6 months to get dental and oral health care. There's many factors which made a person doesn't get dental and oral health as is proper. ${ }^{32}$ Education, socialeconomy, tool and infrastructure factor also played an important role in getting the chance to obtain dental and oral health care in Papua. ${ }^{33}$

According to Papua Provincial Health
Department in 2003, number and distribution of dental and mouth care workers in Papua were not enough. Jayapura as the capital of the province only being served by 9 dentists from outside Papua. Every residence only have 1 or 2 dentist, even in some residence they don't have dentist. Duty and role of dentist were taken by nurses. Very remote geographic location became the reason for dentist not to cover those places in his service area.

\section{CONCLUSION}

Caries prevalence in Papuan students with betel chewing habit in Cilaki Papuan Students Dormitory Bandung in 2007 is high. DMF-T index in Papuan students with betel chewing habit in Cilaki Papuan Students Dormitory Bandung in 2007 is in the high category.

\section{REFERENCES}

1. Reichart PA, Schinidtberg W, Scheifele $\mathbf{C H}$. Betel chewer's mucosa in elderly Cambodian women. J Oral Pathol Med 1996;25:367-70.

2. Yang MS, Su IH, Wen JK, Ko YC. Prevalence and related risk factor of betel quid chewing by adolescent student in Southern Taiwan. J Oral Pathol Med 1996;25:69-71.

3. Wilson DF, Grapping G, Miquel JL. Traditional, culture and ritual practices involving the teeth and orofacialtissue. In: Parabu, S.R. Oral Disease in the tropics. J Oxford University Press 1992.

4. Natamiharja L, Sama R. Kebiasaan mengunyah sirih dan hubungannya dengan indeks penyakit periodontal pada wanita di Kecamatan Lau Belang Kabupaten Karo. J Dentika FKG USU Medan 2004;9(2):84-90.

5. Wanaha MAL. Hasil wawancara kompas dengan dosen FISIP UNCEN Jayapura. Kompas edisi 24 September 2003. [cited 2007 Jan 31]. Available from:http: / / www.kompas.com/kompascetak/0309/24/iptek/578008.htm 2003.

6. Sastroamidjojo AS. Obat asli indonesia khusus daripada tumbuhan-tumbuhan yang ada di Indonesia. Jakarta: Penerbit Dian Rakyat.1967.

7. Heyne K. Tumbuhan Berguna Indonesia. Jilid I \& II. Jakarta: Departemen Kehutanan R.I. 1987. 
8. Suwondo Syarif, dkk. Aktifitas antibakteri daun sirih (Piper betel Linn) Terhadap bakteri gingivitis dan bakteri pembentukan plak atau karies gigi (Streptococcus Mutans). J Indonesian Medicinal Plants 1991;1(1):1-4.

9. Cheeke PR. Toxicants of plants origin Vol. IV Phenolics. Florida. CRC Press, Inc. 1989.

10. Suwondo S. Upaya meninggkatkan manfaat tumbuhan obat tradisional Indonesia untuk pencegahan karies dan gigngivitis berdasarkan ujiaktivitas antibakteriterhadapStreptococcus mutans dan uji klinik terhadap gingivitis. Disertasi. Bandung: Universitas Padjadjaran. 1993.

11. Soemardi R.et al Pengaruh menguyah sirih pada gigi geligi dan mulut. Majalah PDGI 1958;50:14-23.

12. Soebandhi H dkk. Pengaruh Pengunyahan Sirih Terhadap Gusi dan Gigi Geligi. Yogyakarta: Bagian Kesehatan Gigi dan Mulut. Fakultas Kedokteran Gigi Universitas Gadjah Mada. 1978.

13. De Biase CB. Dental health education theory and practice. Philadelphia: Lea and Febiger. 1991.

14. Departement Kesehatan RI. Suvey SKRT DEPKES RI. Kantor Pusat Berita Nasional. [cited 2007 Feb 26]. [cited 2007 Jan 31]. Available from: http: / / www. antara.co.id/print/?id=47493. 2001.

15. Sujatminingsih R. Prevalensi karies gigi dan indeks DMF/def pada penduduk asli kabupaten Fak-Fak Papua. Skripsi. Bandung: Fakultas Kedokteran Gigi Universitas Padjadjaran. 1994.

16. Kidd EAM, Joyston-Bechal S. Essential of dental caries the desease and its management. $2^{\text {nd }} e d$. New York: Oxford University Press Inc. 1997.

17. Mount GJ, Hume WR. Preservation and restoration of tooth structure. London: C.V. Mosby Co. 2005.

18. Wang, Chin-Kun, Wen-Hsiu Lee, Chin-Hui Peng. Contents of phenolics and alkaloids in Areca catechu Linn during maturation. American Chemical Society. J Agric. Food Chem 1997;45(4):1185-8.

19. Darwis SN. Potensi (Piper betle L) sebagai tanaman obat. J Indonesian Medicinal Plants 1992;1:9-11.

20. Vasu S. Betel chewing. National Library
Board. Singapore. 1999 Available from: http: / / econtent.elibraryhub.com/SHC/ Singapore\%20Pages/ infopedia.

21. Roneey DF. Betel chewing traditionsin SouthEast Asia. New York: Oxford University Press. 1993.

22. Quisumbing E. Medical plants of the Philippines. Techinical Bulletin No.16. Republic of Philippines: Depertement Of Agricultural and Natural Resources. 1951.

23. Sundari S, Koensoemardija, Nusratini. Minyak atsiri sirih dalam pasta gigi stabilitas fisis dan daya antibakteri. J Indonesian Medicinal Plants 1992;1:1,5-6.

24. Hendrayani SF. Pengaruh beberapa ekstrak daun sirih terhadap pertumbuhan Candida albicans. Tesis. Pascasarjana. IPB Bogor: 2005

25. Mostehy MRE, at al. Oral submucous fibrosisReview and case report. Saudi Dental J 1989;1(2):60-4.

26. Deng JF, et.al. Acute toxicities of betel nut: rare but probably overlooked events. Clinical toxicology. J Veterans General Hospital-Taipei \& School of Medicine. NationalYang-Ming University Press. 2001.

27. Prawiranata W, Harran S, Tjondronegoro P. Dasar-dasar fisiologi tumbuhan. Jilid II. Bogor: Departemen Botani. FTP IPB. 1981.

28. Pickwell SM, Samrang S, Lawrence AP. Betelmania'betel quid chewing by Cambodian women in the United States and its potential health effects. West J Med La Jolla, California 1994:160:326-33.

29. Hasibuan S. Karakteristik penyirih di Kabupaten Tanah Karo Sumatera Utara. Maj Il Kedokt Gigi. FKG USAKTI. 2005;20(60).

30. Axelsson P. Diagnosis and risk predilection of dental caries. Vol.2. Illinois: Quintessence Publihing Co, Inc. 2000.

31. Fejerskov O, Kidd EAM. Dental caries the desease and its clinical managemen. Denmark. Blacwell Publishing Co. 2003.

32. Harris O. Norman and Christen, G. Arden. Primary Preventive Dentistry $4^{\text {th }}$ ed. USA: Aplleton \& lange. 1995

33. Cendrawasi Post. Menelusuri kesehatan gigi dan mulut di Papua. Edisi 10 Oktober 2003. Cepost. Jayapura. Diakses melalui http:// www.Cendrawasi Post. Com. Tanggal 29 Mei 2004. 2003 